\title{
Decolourisation of a synthetic textile effluent using a bacterial consortium
}

\author{
Patrícia A. Ramalho ${ }^{7}$, M. Helena Cardoso ${ }^{7}$, M. Teresa Ramalho², Georg M. Gübitz ${ }^{3}$ and \\ Artur M. Cavaco-Paulo 4 \\ 'University of Minho, Department of Biology, Braga, Portugal \\ ${ }^{2}$ University of Minho, Department of Chemistry, Braga, Portugal \\ ${ }^{3} \mathrm{Graz}$ University of Technology, Department of Environmental Biotechnology, Graz, Austria \\ ${ }^{4}$ University of Minho, Department of Textile Engineering, Guimarães, Portugal
}

In the present study we examined the performance of a thermoalkalophilic bacterial consortium, where the predominant strain was Bacillus sp. SF, in the degradation of Reactive Black 5 (RB5). We used a reactor working in continuous mode and investigated the effects of $\mathrm{pH}$, hydraulic retention time (HRT) and several added salts on colour and chemical oxygen demand (COD) re-


achieved were $91.2 \pm 0.8 \%$ for colour removal and $81.2 \%$ for COD removal. The system tolerated, with no significant decrease in colour removal efficiency, $30 \mathrm{~g} / \mathrm{L} \mathrm{Na}_{2} \mathrm{SO}_{4}, \mathrm{Na}_{2} \mathrm{CO}_{3}$ or $\mathrm{NaCl}$. The latter two salts, however, led to a reduction in COD removal of $30 \%$ and $50 \%$, respectively. The system proved to be very effective in the decolourisation of C.I. RB5 under alkaline conditions and at a comparatively high temperature.

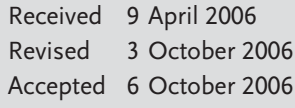

Keywords: Azo dye - Bacterial consortium - Bioreactor - Decolourisation - Reactive Black 5

Azo dyes are easily reduced to colourless amines; however, in conventional biological treatment systems, like activated sludge, the prevailing aerobic conditions usually prevent complete reductive azo dye decolourisation [1-3]. Therefore, the treated water still needs some kind of tertiary treatment. Additional problems met in the treatment of wastewaters generated by dyeing with reactive azo dyes are the high temperature and $\mathrm{pH}$ values and the high salt content of reactive dye baths [4-7]. Therefore, in the last few years, intensive research has been performed in the azo dye biodegradation area, mainly with bacteria, either isolated or in consortia [2, 8-11], aiming at the pro-

Correspondence: Dr. Patrícia A. C. F. Ramalho, Biology Department, University of Minho, Campus de Gualtar, 4710-057 Braga, Portugal E-mail: patramalho@bio.uminho.pt

Fax: +351-253-678980

Abbreviations: COD, chemical oxygen demand; HRT, hydraulic retention time; RB5, C.I. Reactive Black 5; TSS, total suspended solids; TS, total solids; TVS, total volatile solids; VSS, volatile suspended solids duction of wastewaters complying with the applicable legislation. In Portugal, for instance, the limits for discharge of effluents from textile industries are as follows: pH between 5.5 and 9 (Sorensen scale), biochemical oxygen demand after 5 days $<100 \mathrm{mg} \mathrm{O}_{2} / \mathrm{L}$, chemical oxygen demand (COD) <250 $\mathrm{mg} \mathrm{O}_{2} / \mathrm{L}$, and colour not visible at a dilution of 1:40 [12]. These limits prevail over general regulations [13] for the discharge of residual waters.

In a biological system for wastewater remediation, the first consideration to be made relates to the choice of the biological material. In this respect, the use of bacterial consortia has several advantages. Firstly, they do not require sterile conditions, thus greatly reducing costs. Secondly, they are usually more stable towards changes in $\mathrm{pH}$, temperature and feed composition, when compared with pure cultures [1]. Finally, there is a higher possibility of a complete mineralization of the dye since few strains have been found that can metabolise these types of compounds alone [8]. However, the operational parameters of a biological treatment system greatly influence its efficiency, and parameters such as hydraulic retention time 
(HRT), aeration level, temperature and $\mathrm{pH}$ must be optimised [8]. Also the microorganisms' ability to use nutrients such as acetate present in the effluents could help to reduce the cost and increase the applicability of a system in industry. Before a treatment system can be applied to industrial wastewater all the referred parameters must be studied and optimised.

The main goal of this study was to assess the influence of HRT, pH and the presence of common salts in reactive dye baths on the colour and COD removal efficiencies of a bacterial bioreactor applicable to the treatment of alkaline and coloured wastewaters at high temperature. A thermoalkalophilic bacterial consortium in which the predominant strain is Bacillus sp. SF was selected, based on the potential of its azoreductase to reduce azo dyes, as reported earlier $[14,15]$. The reactor was operated at $\mathrm{pH} 9$ and $55^{\circ} \mathrm{C}$ because reactive dyes are used under alkaline conditions at high temperatures. The chosen dye was C.I. Reactive Black 5 (RB5), one of the most widely used in cotton dyeing processes.

The bacterial consortium used in this work was isolated from a wastewater drain of a textile finishing company (Têxtil Alberto de Sousa, Guimarães, Portugal) based on its ability to degrade various dyestuffs at $\mathrm{pH} 9$ and $60^{\circ} \mathrm{C}$ as previously described [14]. After a period of acclimation, the established bacterial consortium inside the reactor was found to be predominantly constituted by the Bacillus sp. SF strain $[14,15]$.

RB5 (min. dye content 55\%) was purchased from Aldrich and used without further purification. Inorganic media components, as well as glucose, were purchased from Merck. Peptone from casein and yeast extract were purchased from Difco. RB5 was used as a $0.4 \%$ solution in nutrient medium, which contained $2 \mathrm{~g} / \mathrm{L}$ casein peptone, as carbon source, and $1 \mathrm{~g} / \mathrm{L}$ yeast extract in a mineral salts solution with the following composition: $3.5 \mathrm{~g} / \mathrm{L} \mathrm{KH}_{2} \mathrm{PO}_{4}$, $7.5 \mathrm{~g} / \mathrm{L} \quad \mathrm{Na}_{2} \mathrm{HPO}_{4} \cdot 7 \mathrm{H}_{2} \mathrm{O}, 2.5 \mathrm{~g} / \mathrm{L} \quad\left(\mathrm{NH}_{4}\right)_{2} \mathrm{SO}_{4}, 4.5 \mathrm{~g} / \mathrm{L}$ $\mathrm{MgSO}_{4} \cdot 7 \mathrm{H}_{2} \mathrm{O}, \quad 0.2 \mathrm{~g} / \mathrm{L} \quad \mathrm{MnSO}_{4} \cdot \mathrm{H}_{2} \mathrm{O}$ and $0.7 \mathrm{~g} / \mathrm{L}$ $\mathrm{FeC}_{6} \mathrm{H}_{5} \mathrm{O}_{7} \cdot 5 \mathrm{H}_{2} \mathrm{O}$. Trace elements were provided by the addition of $0.25 \%$ of the SL- 6 trace element solution according to Pfennig [16]. All solutions were prepared with distilled water. To avoid precipitation of the salts during autoclave sterilisation, magnesium, manganese and iron salts were autoclaved separately and aseptically combined with the other components. Except where stated otherwise, medium $\mathrm{pH}$ was adjusted to $9.0 \pm 0.2$ with $\mathrm{NaOH}$.

The bioreactor (scheme shown in Fig. 1) consisted of a cylindrical vessel $9 \mathrm{~cm}$ in diameter and $15 \mathrm{~cm}$ high (up to the conical top), filled with $0.65 \mathrm{~L}$ of a Leca ${ }^{\circledR}$ (expanded clay balls) carrier, produced and purchased from Dansk LecaA/S, Hinge/Randers, Denmark. The working volume was $0.45 \mathrm{~L}$. A metal filter was fitted to the conical top to avoid the carrier washout. Except where stated otherwise, the reactor was operated at a flux of $37.5 \mathrm{~mL} / \mathrm{h}$ (corresponding to an HRT of $12 \mathrm{~h}$ ), under an aeration flux of
$300 \mathrm{~mL} / \mathrm{min}$. The system also included an aeration pump Tagus 3000 and a feed pump Gilson model Minipulse2. The reactor temperature was maintained at $55 \pm 2^{\circ} \mathrm{C}$ by a coil of flexible silicone tubing connected to a water bath at $60 \pm 1^{\circ} \mathrm{C}$. Whenever operating conditions were changed, the reactor was allowed to stabilize for four cycles (four times the HRT). Samples were collected daily from the reactor effluent.

The dye content in samples was calculated by absorbance measurements at $560 \mathrm{~nm}$ against a water blank. Samples were filtered with $0.20-\mu \mathrm{m}$ membranes and diluted as required. Total suspended solids (TSS), total solids (TS) and total volatile solids (TVS) were determined by standard gravimetric methods [17]. The COD of dissolved matter was measured in filtered samples, using a $\mathrm{HACH}$ spectrophotometer model DR/2000, following the manufacturer's instructions for the $\mathrm{HACH}$ high range COD test (0-1500 ppm). All the presented results are the average of three independent determinations, except for COD analyses relating to the effect of salts, for which all collected samples were mixed to make a single composite sample for each salt tested. The reactor was operated for 380 days, during which the effects of HRT, pH and salts addition in the reactor performance were examined.

The influence of HRT on colour and COD removal is depicted in Fig. 2A. HRT colour removal efficiency increased from $\sim 87 \%$ to $92 \%$ between 6 and $12 \mathrm{~h}$, reaching $\sim 95 \%$ at an HRT of $24 \mathrm{~h}$. COD removal remained almost constant ( $62 \%)$ between an HRT of 6 and $10 \mathrm{~h}$, increasing to $81 \%$ at $12 \mathrm{~h}$, and to $89 \%$ at $24 \mathrm{~h}$. The low COD removal at low HRTs is possibly due to the incomplete consumption of medium nutrients, which account for the total COD amount. Despite the small difference in the values obtained for HRT $<12 \mathrm{~h}$, the existence of a dye adsorption step prior to biodegradation (that would limit the degradation rate until $12 \mathrm{~h}$ of HRT) may also be possible. After that the degradation rate would be controlled by the biodegradation mechanism. Considering the modestly efficient increase in colour and COD removal between

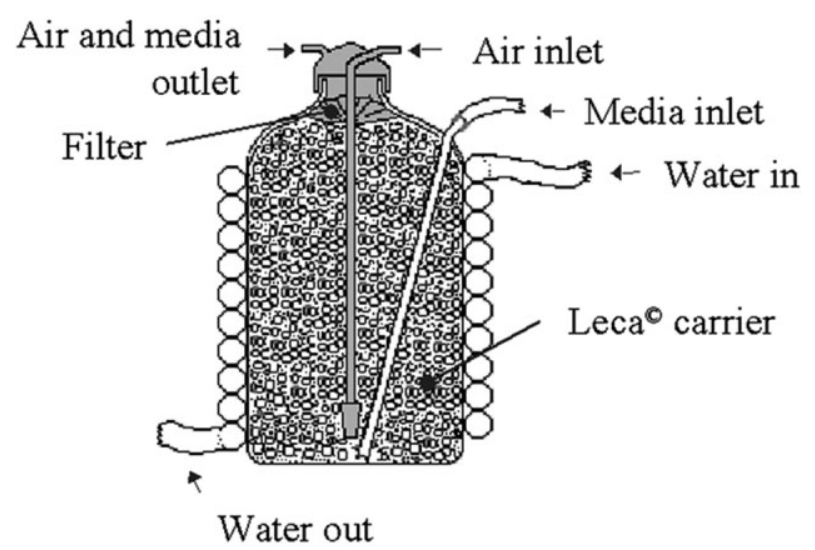

Figure 1. Scheme of the lab scale reactor for continuous decolourisation. 


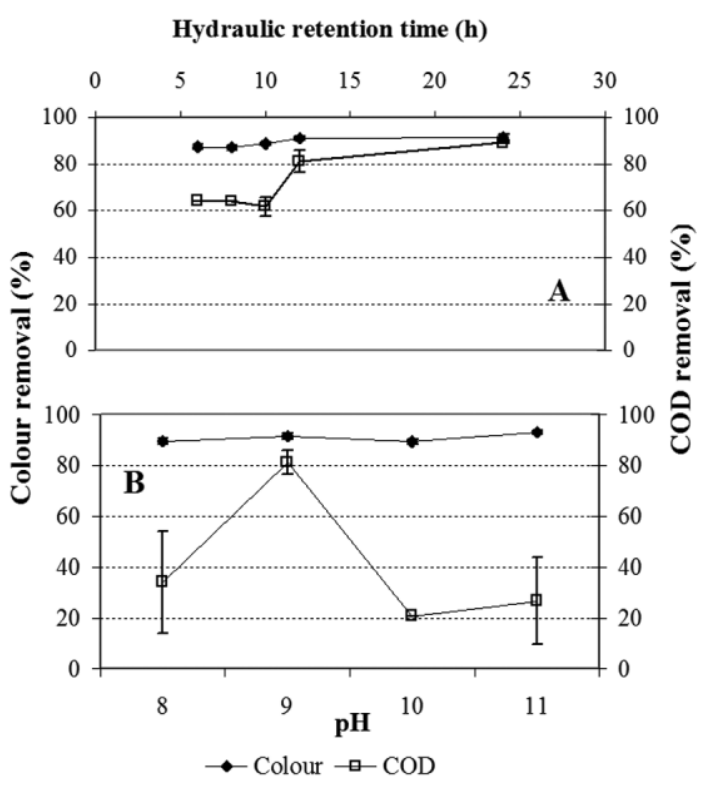

Figure 2. (A) Effect of the HRT on colour and COD removal efficiencies at $\mathrm{pH} 9$ and $55 \pm 2^{\circ} \mathrm{C}$ (mean values and SD). (B) Effect of $\mathrm{pH}$ on colour and COD removal efficiencies at $12 \mathrm{~h}$ of HRT and $55 \pm 2^{\circ} \mathrm{C}$ (mean values and SD).

12 and $24 \mathrm{~h}$, subsequent experiments were performed with an HRT of $12 \mathrm{~h}$.

As the used consortium is alkalophilic, $\mathrm{pH}$ was varied between 8 and 11, and the results are shown in Fig. 2B. Within the tested range, dye removal did not significantly change; however, for COD removal, a maximum was observed at pH 9. Again since COD is primarily due to nutrient substrates, these results suggest that the consortium has an optimum metabolic activity at that $\mathrm{pH}$.

The effects of $30 \mathrm{~g} / \mathrm{L} \mathrm{NaCl}, \mathrm{Na}_{2} \mathrm{SO}_{4}$ and $\mathrm{Na}_{2} \mathrm{CO}_{3}$ were also investigated. In the dyeing processes, these salts are used mainly as auxiliaries to ensure maximum fixation of dye to the fibre $[4,18]$. As shown in Table 1 , the tested concentration did not significantly affect colour removal. In contrast, COD removal was negatively affected, particularly by $\mathrm{NaCl}$. The same type of behaviour has been observed in an up-flow anaerobic sludge blanket reactor [18]. An explanation for this effect is that high salt concentrations ( $>1 \%$ ) cause plasmolysis and/or loss of cell activity [19]. However, since efficiency in colour removal was not significantly decreased, the hypothesis of dye adsorption to biomass and/or carrier, as an initial step before biodegradation, cannot be discarded. It is also known that chloride anions increase COD [20]. This was verified in the increase value of COD in the fed of the reactor when $\mathrm{NaCl}$ was added, and could also have made a contribution to the decreased COD removal efficiency.

During reactor operation frequent analyses of the TSS in the collected samples (liquid phase) were performed. The mean value $( \pm \mathrm{SD})$ during the operation of the reactor
Table 1. Effect of the presence of $30 \mathrm{~g} / \mathrm{L}$ of $\mathrm{NaCl}, \mathrm{Na}_{2} \mathrm{SO}_{4}$ and $\mathrm{Na}_{2} \mathrm{CO}_{3}$ on colour and COD removal efficiencies at $12 \mathrm{~h}$ of HRT at pH 9 and $55 \pm 2^{\circ} \mathrm{C}$

\begin{tabular}{lcc}
\hline & Colour removal (\%) & COD removal (\%) \\
\hline Control & $91.2 \pm 0.8$ & 81.2 \\
$30 \mathrm{~g} / \mathrm{L} \mathrm{NaCl}$ & $89.7 \pm 1.7$ & 31.0 \\
$30 \mathrm{~g} / \mathrm{L} \mathrm{Na}_{2} \mathrm{SO}_{4}$ & $92.4 \pm 0.2$ & 78.9 \\
$30 \mathrm{~g} / \mathrm{L} \mathrm{Na}_{2} \mathrm{CO}_{3}$ & $92.1 \pm 0.4$ & 51.6 \\
\hline
\end{tabular}

was $0.54 \pm 0.22 \mathrm{~g} / \mathrm{L}$. The lowest values were obtained for the operation at $\mathrm{pH} 11(0.23 \pm 0.11 \mathrm{~g} / \mathrm{L})$. This high average amount of solids in the effluent is not totally unexpected since the degradation achieved is high, meaning that the production of biomass is also high. Increasing the HRT, the amount of suspended solids in the effluent was increased as expected, although not very significantly (from $0.60 \pm 0.03 \mathrm{~g} \mathrm{TSS} / \mathrm{L}$ at $8 \mathrm{~h} \mathrm{HRT}$ to $0.68 \pm 0.04 \mathrm{~g} \mathrm{TSS} / \mathrm{L}$ at $24 \mathrm{~h} \mathrm{HRT)}$. The considerable variability in the observed results is, primarily, a consequence of factors related to the reactor's design, particularly clogging, which lead to oscillations in the aeration flux, biomass loss and development of anaerobic areas. Therefore, the application of this system in industry would require a more efficient aeration system and a sedimentation process in the effluent of the reactor since the amount of solids largely exceeds the allowed upper limit for discharge into an aquatic environment (in Portugal this is $60 \mathrm{mg} / \mathrm{L}$ [13]).

The biomass present inside the reactor, i.e., the biomass in suspension plus the biomass attached to the carrier, was determined as TVS. For determination of the attached biomass, four independent collections of carrier were performed. These samples were washed with water, dried at $85^{\circ} \mathrm{C}$, weighted (W1), dried at $550^{\circ} \mathrm{C}$, weighted (W2), washed again, dried at $85^{\circ} \mathrm{C}$ and weighted again (W3). The amount of TVS was determined by: TVS (mg $\mathrm{VS} / \mathrm{g}$ carrier $)=(\mathrm{W} 1-\mathrm{W} 2-\mathrm{W} 3) / \mathrm{W} 3$. An average value of $16 \pm 3.3 \mathrm{~g}$ TVS was obtained, from which approximately $4.5 \pm 0.5 \%$ was in suspension. The carrier adsorbed an average of $20.6 \pm 4.3 \mathrm{mg}$ TVS/g carrier.

In summary, the major outcome from this study was the demonstration that this alkali-thermophilic bacterial consortium is also salt tolerant, achieving 90\% colour removal at $\mathrm{pH} 9.0$ and $55^{\circ} \mathrm{C}$, even in the presence of the tested salts. These are important advantages in the treatment of hot, high-salt wastewaters generated by dyeing bath. However, the production of VSS is still far too high for discharge and COD removal is negatively affected by salts, particularly by $\mathrm{NaCl}$, which decreases this parameter from $80 \%$ to $\sim 30 \%$. Future work will require a tighter control of aeration inside the reactor (to minimise clogging, channelling and consequent development of anaerobic areas), optimisation of the ratio of carbon source/dye, the investigation of the mechanism(s) responsible for colour loss, the testing of other reactive dyes and the use of real wastewaters. 
P.R. gratefully acknowledges a PhD scholarship from the European Project BIOEFTEX and a post-doc scholarship from Fundação para a Ciência e Tecnologia (SFRH/ BPD/20704/2004).

\section{References}

[1] Forgacs, E., Cserhati, T., Oros, G., Removal of synthetic dyes from wastewaters: a review. Environ. Int. 2004, 30, 953-971.

[2] Robinson, T., McMullan, G., Marchant, R., Nigam, P., Remediation of dyes in textile effluent: a critical review on current treatment technologies with a proposed alternative. Bioresour. Technol. 2001, 77, 247-255.

[3] Ganesh, R., Boardman, G. D., Michelsen, D., Fate of azo dyes in sludges. Water Res. 1994, 28, 1367-1376.

[4] Correia, V. M., Stephenson, T., Judd, S. J., Characterisation of textile wastewaters - a review. Environ. Technol. 1994, 15, 917-929.

[5] Delée, W., O'Neill, C., Hawkes, R. F., Pinheiro, H. M., Anaerobic treatment of textile effluents: a review. J. Chem. Technol. Biotechnol. 1998, 73, 323-335.

[6] Allègre, C., Moulin, P., Maisseu, M., Charbit, F., Treatment and reuse of reactive dyeing effluents. J. Membr. Sci. 2006, 269, 15-34.

[7] Rodriguez, M., Sarria, V., Esplugas, S., Pulgarin, C., Photo-Fenton treatment of a biorecalcitrant wastewater generated in textile activities: biodegradability of the photo-treated solution. J. Photochem. Photobiol. 2002, 151, 129-135.

[8] Pearce, C. I., Lloyd, J. R., Guthrie, J. T., The removal of colour from textile wastewater using whole bacterial cells: a review. Dyes Pigments 2003, 58, 179-196.

[9] Chung, K.-T., Stevens, S. E. Jr., Degradation of azo dyes by environmental microorganisms and helminths. Environ. Toxicol. Chem. 1993, 12, 2121-2132.
[10] Banat, I. M., Nigam, P., Singh, D., Marchant, R., Microbial decolorization of textile-dye-containing effluents: a review. Bioresour. Technol. 1996, 58, 217-227.

[11] Stolz, A., Basic and applied aspects in the microbial degradation of azo dyes. Appl Microbiol Biotechnol 2001, 56, 69-80.

[12] Portaria n423/97 (Portuguese legislation), 25 June 1997.

[13] Decreto Lei n²36/98 (Portuguese legislation), 1 August 1998.

[14] Paar, A., Costa, S., Tzanov, T., Gudelj, M. et al., Thermo-alkali-stable catalases from newly isolated Bacillus sp. for the treatment and recycling of textile bleaching effluents. J. Biotechnol. 2001, 89, 147153.

[15] Maier, J., Kandelbauer, A., Erlacher, A., Cavaco-Paulo, A. et al., A new alkali-thermostable azoreductase from Bacillus sp. strain SF. Appl. Environ. Microbiol. 2004, 70, 837-844.

[16] Pfennig, N., Rhodopseudomonas globiformis sp. n., a new species of Rhodospirillaceae. Arch. Microbiol. 1974, 100, 197-206.

[17] American Public Health Association (APHA)/American Water Works Association (AWWA)/Water Environment Federation (WEF), Physical and aggregate properties, in: APHA Standard Methods for the Examination of Water and Wastewater, 18th edn. APHA/AWWA/ WEF, Washington, D.C. 1992, pp. 2-55-2-59.

[18] Isik, M., Efficiency of simulated textile wastewater decolorization process based on the methanogenic activity of an upflow anaerobic sludge blanket reactor in salt inhibition condition. Enzyme Microb. Technol. 2004, 35, 399-404.

[19] Kargi, F., Dincer, A. R., Effect of salt concentration on biological treatment of saline wastewater by fed-batch operation. Enzyme Microb. Technol. 1996, 19, 529-537.

[20] Chatzisymeon, E., Xekoukoulotakis, N. P., Coz, A., Kalogerakis, N., Mantzavinos, D., Electrochemical treatment of textile dyes and dyehouse effluents. J. Hazard Mater. 2006, B137, 998-1007. 